TEME, г. XLIV, бр. 3, јул - септембар 2020, стр. 681-701

Оригинални научни рад https://doi.org/10.22190/TEME200310052S

Примљено: 10. 3. 2020.

UDK 316.356.2:159.942

Ревидирана верзија: 2. 7. 2020.

Одобрено за штампу: 1. 10. 2020.

\title{
GENDER ROLES AND DIMENSIONS OF FAMILY FUNCTIONING AS PREDICTORS OF SUBJECTIVE WELL-BEING IN MEN AND WOMEN
}

\author{
Miljana Spasić Šnele*, Jelisaveta Todorović, Miroslav Komlenić \\ University of Niš, Faculty of Philosophy, Niš, Serbia \\ *miljana.spasic.snele@filfak.ni.ac.rs
}

\begin{abstract}
Subjective well-being (a positive attitude towards life and positive affectivity) as an important indicator of mental health attracts a lot of attention in the field of positive psychology. For the sake of improving mental health, research was mainly focused on identifying factors related to it. So far, findings indicate there is a need for a better understanding of the characteristics of both individual and family environments. To that end, the aim of this study was to examine gender differences and what contributes to the subjective well-being of men and women. The study examined gender roles, masculinity and femininity, aspects of family functioning, education and the number of children. The sample included 1417 respondents who are married or in a relationship (586 men, 802 women), and the following questionnaires were used: a shorter versions of the Subjective Well-Being Scale, the Masculinity and Femininity Scale and the Family Functioning Scale, as part of the larger PORPOS 2 battery. The results showed that masculinity and femininity, and adequate communication in the family are important indicators of a positive attitude towards the life of both genders. Masculinity and satisfaction with communication play a significant role when it comes to the positive affectivity in both men and women. The level of cohesiveness also plays an important role in the subjective well-being of men, and the number of children is a negative predictor of both dimensions of subjective well-being in women. Based on these results, we can conclude that a better understanding of the subjective well-being of men and women requires a more focused approach, which can be important in both research and psychotherapeutic work.
\end{abstract}

Key words: subjective well-being, gender roles, dimensions of family functioning, gender, education, number of children. 


\title{
ПОЛНЕ УЛОГЕ И ДИМЕНЗИЈЕ ПОРОДИЧНОГ ФУНКЦИОНИСАҢА КАО ПРЕДИКТОРИ СУБЈЕКТИВНОГ БЛАГОСТАҢА МУШКАРАЦА И ЖЕНА
}

\begin{abstract}
Апстракт
Субјективно благостање (позитиван став према животу и позитиван афективитет), као значајан показатељ менталног здравља у области позитивне психологије, последњих деценија привлачи велику пажњу истраживача. У циљу унапређења менаталног здравља, истраживачка питања била су усмерена на препознавање фактора који су повезани са њим. Испитивања су указала на потребу за бољим разумевањем не само индивидуалних обележја већ и карактеристика породичног окружења. У складу са тим, циљ овог истраживања био је да се испита шта доприноси субјективном благостању мушкараца и жена и постоје ли у том погледу полне разлике. Испитиване су полне улоге, маскулиност и фемининост, различити аспекти породичног функционисања, као и образовање и број деце. У узорку истраживања учествовало је 1417 испитаника, који су у браку или партнерској вези (586 мушкараца, 802 жена). У циљу прикупљања података о варијаблама, примењени су следећи упитници: краће верзије Скале субјективног благостања, Скале маскулиности и фемининости и Скала породичног функционисања, као део веће батерије PORPOS2. Резултати су показали да маскулиност и фемининост, заједно са адекватном комуникацијом у породици, представљају важне индикаторе позитивног става према животу оба пола. Маскулиност и задовољство комуникацијом имају значајну улогу када је реч о афективној димензији субјективног благостања код оба пола. На узорку мушкараца важну улогу има и ниво кохезивности, а код жена број деце се негативно одражава на димензије субјективног благостања (позитиван став према животу и позитиван афективитет). На основу добијених резултата, можемо закључити да боље разумевање субјективног благостања мушкараца и жена захтева усмеренији приступ, који може бити од важности како у истраживачком тако и психотерапијском раду.
\end{abstract}

Кључне речи: субјективно благостање, родне улоге, димензије породичног функционисања, пол, образовање, број деце.

\section{INTRODUCTION}

\section{Subjective Well-Being}

Following a relatively long period of dealing with pathological aspects of personality, positive psychology gradually entered science, posing the question of what it is that makes one happy. In search for an answer to this question, it was necessary to form a new research corpus with, until then, underrepresented concepts, such as optimism, quality of life, resilience, coping strategies, subjective well-being.

Subjective well-being can be described as follows:

"It refers to people's evaluations of their lives, which can be judgments such as life satisfaction, evaluations based on feelings, including moods and emotions" (Diener \& Chan, 2011, pp. 1-2). 
Here we note that the assessment of subjective well-being encompasses both cognitive and emotional (affective) domains (Diener, 1984; cited in Hadži-Pešić \& Anđelković, 2013). Satisfaction with life is based on the cognitive evaluation of life in general or in relation to the domains of life important for an individual, such as marriage, family, job, friends, etc. The degree of satisfaction with life is in the function of how our physical, economic and psychological wishes are fulfilled. When it comes to this dimension of subjective wellbeing, in literature, the difference between satisfaction with life and positive attitude towards life is pointed out, and it refers to the positive evaluation of life and optimistic attitude towards life. Although similar conceptually, the difference stems from operative definitions of these notions, whereby items on the cognitive subscale Short scale of subjective well-being refer to a generally positive attitude towards life (Jovanović 2010).

The emotional (affective) component of subjective well-being is made of both positive and negative affect (Hadži-Pešić \& Anđelković, 2013). Positive affectivity refers to the degree to which a person expresses their satisfaction, enthusiasm and other positive emotional states such as joy, excitement, liveliness. Research have shown that many social behaviors correlate with positive affectivity, such as numerous close friends and relatives, constant contact with them, involvement in social organizations, extroversion, physical activity and religiousness. On the other hand, negative affectivity refers to the degree to which an individual is prone to irritability, distress and anger. It is about subjective distress and dissatisfaction combined with negative emotional states such as anger, fear, sadness, guilt (Joshi, 2010). Surely, some negative emotions are impossible to avoid, they are part of life and can be necessary for effective functioning, but frequent and prolonged negative emotions indicate that a person's life is proceeding badly.

The better understanding of subjective well-being implies recognizing factors related to it, and one of the research questions referred to gender differences in experiencing subjective well-being. The results of the research are not consistent. Certain studies showed that men have significantly higher levels of subjective well-being (Stevenson \& Wolfers, 2009), while other studies have shown that women have significantly higher levels of subjective well-being (Fujita, Diener, \& Sandvik, 1991). However, some research proved that there are no significant differences between the genders (BatzBarbarich, Tay, Kuykendall, \& Cheung, 2018; Okun \& George, 1984). Batz and Tay (2018) point to three groups of factors which may be singled out in order to explain gender differences in the assessment of subjective wellbeing: 1) the structural factors (i.e. differences in institutional arrangements and opportunities between men and women), 2) the socio-cultural factors (i.e. differences in societal expectations and norms for men versus women), and 3) biological differences (i.e. physical and physiological differences). We note that social factors have an important role in experiencing subjective 
well-being, whether through the opportunities to achieve individual potentials, whether through determined, most often different expectations from men and women, with which an individual identifies with time, internalizing them so that these expectations gradually become a measure of self-evaluation. Traditional and egalitarian understanding of social roles undoubtedly has a particular place in experiencing subjective well-being of men and women.

\section{Gender Roles}

"Differences in the norms and expectations for men and women, referred to in the literature as "gender roles" (Batz \& Tay, 2018, p. 7). They can be understood as socially and culturally held stereotypes regarding the characteristics, emotions and behavior, and even occupation that are acceptable for men and women (Batz \& Tay, 2018; KandidoJakšić, 1995; Mihić \& Filipović, 2012).

Whereas gender represents a biological determinant with which each individual is born, gender appears under the influence of socialization. Various experiences with the environment reactions to behavior attributed to sex and direct teaching have a particularly important role in that process (Mihić \& Filipović, 2012), contributing that already at the age of three we notice significant gender categories of behavior (Kandido-Jakšić, 1995). Behavior of both parents towards their male and female children significantly contributes in that process. Suffice to say that fathers in particular punish and suppress feminine behavior in boys much more than masculine behavior in girls (Maccoby \& Jacklin, 1974; Bakan, 1966; Dropplleman \& Schaefer, 1963; cited in Kandido-Jakšić, 1995; Rubin, Provenzano, \& Luria, 1974; cited in Mihić \& Filipović, 2012). Thus, since their earliest days, boys are expected to develop specific masculine characteristics, such as aggressiveness, ambition, physical strength, competitiveness, rationality, success, dominance, self-confidence, ability to take risks, courage and toughness so as to successfully accomplish their traditional role of breadwinner (Kandido-Jakšić, 1995). On the other hand, girls are expected to adopt special feminine characteristics, which primarily imply the ability to love and sympathize, to satisfy others' needs, to take care of the house and all members of the family, to be emotional, tender, loyal, obedient, uncorrupted and compliant.

In recent years there are more liberal concepts of male and female gender roles, where the concept of androgyny undoubtedly had a significant role (Kandido-Jakšić, 1995). Although even Jung, through the concepts of anima and animus whose cognition contributes to mental health, pointed out to the importance of "man" that is "woman" in each individual, it is only through the work of Sandra Bem (1975) that this idea became accessible for research. Thus, persons who possess positive masculine and feminine characteristics are called androgynous. When it 
comes to women, androgyny is reflected in the development and realization of their own success and ability outside family, whereas the more modern concept of masculine gender role consists in greater orientation towards family and children upbringing. Such understanding of gender roles indicates that masculinity and femininity may coexist in each individual, to a less or greater extent.

In line with the changes, there are new suggested gender neutral names of these dimensions. The trait which was formerly called "masculinity" is now called "agency," and the trait formerly called "femininity" is now called "communion" (Eddington \& Shuman, 2005), preserving their fundamental sense. More precisely, communion includes characteristics such as warmth, concern for others, and understanding, and agency includes independence, self-confidence, and decisiveness. Although these new terms are preferred to the old terms because they recognize that men or women can possess either set of characteristics (Eddington \& Shuman, 2005), in this paper we shall comply with the term masculinity and femininity in line with the names of the dimensions of the instruments which we applied.

The issue of gender roles in modern literature is closely related to the experience of subjective well-being. According to some results, it seems that greater gender equality is correlated with higher levels of overall happiness (e.g., Bjørnskov, Dreher, \& Fischer, 2007; Inglehart \& Welzel, 2005; Inglehart, Foa, Peterson, \& Welzel, 2008; Jorm \& Ryan, 2014; Ruth \& Napier, 2014; Schyns, 1998; cited in Batz \& Tay, 2018; Read \& Grundy, 2011; Van De Vijver, 2007). However, in certain research slightly different results have been obtained. Meisenberg and Woodley (2015) found that some indicators, including women's involvement in gainful employment and prolonged schooling, are negatively related to women's well-being. A similar understanding is put forward by Jugović (2004; cited in Mihić \& Filipović, 2012) pointing out that in reality, although employed outside the house, women still do most of the housework, which requires permanent balancing between work and family, which as a consequence has great amounts of stress. It seems that at present, a great number of women are in some kind of transition period in which, on the one hand, they are becoming more equal in the professional world, while on the other, strong traditional expectations from the gender role are still present.

\section{Dimensions of Family Functioning}

Since functional family provides sense of security and belonging, and satisfies different needs of its members, it is reasonable to expect that the experience of satisfaction with life and well-being is also related to family functioning. Different aspects of family, such as the number of children, and cohabitation versus official married couples, were examined in order to better understand their roles in satisfaction with life (Kurdek 
1991, Mastekaasa, 1994, Stack \& Eshleman 1998; cited in Shields \& Wooden 2003). In line with that, it is interesting to notice the observation of Diener et al. (1999; cited in Shields \& Wooden, 2003) that married people report being happier and more satisfied with their lives than unmarried. These findings were confirmed in a number of recently done research (Botha \& Booysen, 2014; Evans \& Kelly, 2004, Sari \& Dahlia, 2018). In some other studies, attention was directed to the more complex aspects of the family-function in the subjective well-being of person. For example, in research done by Botha and Booysen (2014) the aspects of family attachment and changeability subscales, and family functioning type (with scale FACI8) were followed as the predictors of life satisfaction and happiness in South Africa. In one other recently conducted study (Sari \& Dahlia, 2018), authors were interested in the dimensions of family function and subjective well-being in adolescents aged 12 to 15 years. The study indicated that family functioning, (assessed by FAD-Family Assessment Device) was significantly related to subjective well-being among adolescents. FAD was designed based on the McMaster Model of Family Functioning (MMFF) - the concept evolved in frames of systemic family psychotherapy. These findings are especially important since they indicate that satisfaction with life and subjective well-being are related with the more complex aspects of family life and that the methodology of research in this filed should rely on the theory of systemic family psychotherapy.

One of the models of studying the patterns of family functioning that is often used in research is the Circumplex Model of Marital and Family Systems. The creator of this model is David Olson. According to the Circumplex Model, significant dimensions of family functioning are family cohesion, family adaptability, i.e. flexibility and communication. According to Olson (2000), family cohesion refers to the emotional bond between family members. Cohesion is focused on how the family makes a balance between togetherness and separation. Based on the Circumplex Model, a very high degree of togetherness (mixed) and a very low degree of togetherness (disengaged) can be a problem for the family and the realization of its educational function.

Flexibility refers to how a family balances stability and change. Family flexibility is defined by the quality and expression of leadership and organization, adjustment and reconciling of family roles, and negotiations between partners (Olson, 2007). An extremely low level of flexibility, the socalled rigidity, as well as excessively flexible family relationships, the socalled chaotic family relationships, are unbalanced and jeopardize the functionality of the family.

Family relationships characterized by the lack of balance tend to show excessive rigidity and control in relationships. There are no negotiations and most decisions are made by the leader. Roles are divided and the rules do not change. Family relationships that are characterized 
by chaos have variable or limited leadership. Decisions are impulsive and reckless. The rules are unclear and they change from person to person. Family systems need both stability and change, and that ability to change, when it takes place at the right time, separates functional families from those that are not.

Family communication is defined as the positive communication skills used by a couple or a family system. The communication is seen as a facilitating dimension that helps families balance their levels of cohesion and flexibility. Clarity, openness, and collaborative problem solving are key aspects of communication (Olson, 2007).

Functional family systems are characterized by a tendency towards stability, maintaining balance, but also the need to adapt to certain life circumstances. The existence of cohesion and togetherness, but with respect for individual differences, encourages individual development and the realization of the educational function of the family (Matejević \& Todorović, 2012). The main premise of the Circumplex Model is: Balanced levels of cohesion and flexibility are the most suitable or optimal family functioning. Unbalanced levels of cohesion and flexibility (very low or very high levels) are associated with problematic family relationships. Communication is a dimension that makes it easier to achieve balance in family life.

FACES is a questionnaire developed to measure and research the Circumplex Model of Marital and Family Systems. Almost a thousand empirical studies have been conducted using the FACES family functioning questionnaire, created by Olson, designed to assess family functioning on the dimensions: cohesiveness, flexibility, and communication (Kouneski, 2000; Olson \& Gorall, 2003; 2007; Olson, 2011). The results of research confirmed that the dimensions of cohesion, flexibility and communication are related to desirable developmental outcomes in family life.

Most sociologists today understand modern family as an affirmation of union and individuality, love and solidarity, open and clear communication, roles based on agreement, ability and affinity (DragišićLabaš, 2002). Change of role is considered as an important indicator of change of family type from traditional towards egalitarian, which is the trend of change in which modern family is moving. The most important role in overcoming traditional family relations when it comes to the division of power within the family pertains to the change of social position of women. The number of families in which parents equally contribute to the family in the material sense is increasing, and the role of fathers in bringing up children becomes more important.

A functional family is made of strong and healthy partner coalition, openly clear and warm mutual communication, appreciation of boundaries and individuality, as well as flexible control, that is agreement between parents and children. Of course, the reflection of functional relationship is good communication with social surroundings and avoiding isolation (Matejević \& Todorović, 2012). 
A modern family in the $21^{\text {st }}$ century relies on the egalitarian division of family roles, balanced adaptability and bond between family members and rich mutual communication, all of which of course contribute to the adoption of gender roles that are no longer as antagonistic as in previous centuries. To what extent adopted gender roles and dimensions of family functioning contribute to subjective well-being and how it is related to education and the number of children is an issue that deserves scientific attention not only because of the change brought by the modern age, but also because of the continuity of research on the importance of various family factors for the experience of subjective well-being.

A review of previous research does not provide a unique answer to the question of the role of children in experiencing the subjective wellbeing of parents. On the one hand, there is no doubt that they give a unique glow to life, but on the other hand, high material costs, and also care, stress and anxiety can have a negative impact on parental life satisfaction (Shields \& Wooden, 2003).

The issue of education also remains open, considering that some studies have shown that it has a significant, positive role when it comes to subjective well-being (Nikolaev, 2018), while in others it has been shown that the effect is small, but negative, possibly due high aspirations that have yet to be met (Shields \& Wooden, 2003).

Having in mind the previous stated, we could expect that:

1. Both high masculinity and femininity would contribute to subjective well-being of both man and women;

2. Since cohesion, flexibility and communications are important factors of family satisfaction, it is predicted that all three dimensions of family functioning will show as significant contributors of higher SWB in both genders;

3. When it comes to sociodemographic variables - education and number of children, the results of previous research are not consistent, so we hope that results of our research will contribute to clarifications of existing findings.

\section{METHOD}

\section{Objective of the Research}

The main goal of this research was to examine whether gender roles (masculinity and femininity) and dimensions of family functioning (cohesion, flexibility and communication) represent significant predictors of subjective well-being in married men and women. We were also interested in examining the role that education and number of children have in subjective well-being of both genders. 


\section{Sample}

The data given in this research represents a part of a wider research whose aim was to examine the relationship at work and in family in Serbia. The sample was formed based on geographical clusters (geographical cluster sample) (Hedrih, Simić \& Ristić, 2013). More precisely, the forming of the sample was done with regard to administrative districts in Serbia and that the ratio between the number of rural and urban locations are roughly proportionate with the share of urban and rural population (Anđelković, Vidanović, \& Hedrih, 2012). Research was conducted at 33 locations (urban and rural areas in Serbia), individually in the homes of the participants with the paper-pencil type of questionnaire.

The total sample consists of 2283 participants. The results presented in this study refer to a sample of persons who stated that they were married or in a romantic relationship, representing 1417 respondents (586 male and 802 female, whereas for 29 participants the data pertaining to gender is missing). The youngest respondent in the sample is 18 years old and the oldest 82 $(\mathrm{M}=42.57, \mathrm{SD}=13.41)$. Regarding the level of education, $7(0.5 \%)$ of the respondents stated that they did not complete primary education, $71(5 \%)$ had completed primary school, $770(54.3 \%)$ finished secondary school, 195 $(13.8 \%)$ have a college degree, $328(23.1 \%)$ have a college or Master's degree and $16(1.1 \%)$ have a Ph.D. degree. When it comes to the structure of the sample considering the number of children, 301 (21.2\%) of the respondents indicated that they did not have children, $297(21 \%)$ had one child, $599(42.3 \%)$ stated that they had two children and $220(15.5 \%)$ reported to have three or more children.

\section{Instruments}

The participants were given the PORPOS battery - an instrument designed for this research which included 389 items (Hedrih et al., 2013). Scales and questionnaires included in this battery were constructed for the purposes of this research or were obtained by adapting or abbreviation of the existent scales and questionnaires, where the items that had highest correlation with the whole scale in previous research were included.

Scale of Subjective Well-being - consists of two scales: positive attitude towards life (item example: I feel that life is full of beautiful surprises) and positive affectivity (item example: I often feel joyful and thrilled) (Hedrih et al., 2013). Each scale consists of two questions taken from the Short Scale of Subjective Well-Being (Jovanović \& Novović, 2008). Participants were asked to respond to the statement using the fivepoint Likert scale (1- strongly disagree to 5- strongly agree). The Cronbach's $\alpha$ coefficient on our sample of the scale Positive attitude towards life is 0,699 , and of the scale Positive affectivity is 0,842 . 
Femininity and Masculinity Scale - consists of four questions, two for assessing femininity (question example: I'm sensitive to the needs of others; I am a cordial person) and two for assessing masculinity (question example: I want to compete; I like to be dominant) using the five-point Likert scale (1- strongly disagree to 5- strongly agree) for answering. The questions were taken from the BEM Gender Inventory Scale (Bem Sex Role Inventory - BSRI, Bem, 1975, according to Hedrih et al., 2013). The Cronbach's $\alpha$ coefficient on our sample of the scale Femininity is 0,612 , and of Masculinity is 0,583. Lower values of Cronbach's $\alpha$ coefficient on our sample could be due to the small number of items that were included in these scales (Pallint, 2009)

Scale of Family Functionality - consists of three scales: cohesion (6 items), flexibility (6 items) and communication (3 items) (Hedrih et al., 2013). Questions related to family cohesion (item example: „Members of our family love to spend time together") and flexibility (item example: „In our family, everyone is ready to take on the responsibilities of another member") were taken or adopted from FACES III (Kouneski, 2000), and questions regarding the communication subscale (item example: „Family members are satisfied with how they interact with each other") were taken from the FACES IV questionnaire (Olson, 2011). Since the instruction of the original questionnaire does not explicitly state to which family the questions refer (family of origin or new formed family), the same principle was followed in our research. Participants were asked to answer on the items using the five-point Likert scale (1- strongly disagree to 5- strongly agree). In our questionnaire, both the cohesion and flexibility scale consist of six questions, and the communication scale includes three questions. The Cronbach's $\alpha$ coefficient on our sample of the scale Cohesion is 0,867 , of the scale flexibility is 0,480 , and of the scale Communication is 0,883 . The lower level of Cronbach's $\alpha$ coefficient of flexibility scale is not surprising having in mind that in previous research similar values were observed (Olson \& Gorall, 2003; Olson \& Gorall 2007; Matejević \& Todorović, 2012).

\section{RESULTS}

In Table 1 means, standard deviations, skewness and kurtosis of examined variables are presented.

According to the results presented in Table 1 we could say that both male and female participant in general have positive attitude towards life and positive affectivity. Femininity is highly presented in both samples, while masculinity is beyond the theoretical mean. Cohesion and communication as dimensions of family functioning are in average positively estimated, and so is flexibility. 
Table 1. Descriptive statistics

\begin{tabular}{lccccccccr}
\hline & \multicolumn{4}{c}{ Male sample } & \multicolumn{4}{c}{ Female sample } \\
\cline { 2 - 10 } & M & SD & Skewness & Kurtosis & M & SD & Skewness & Kurtosis \\
\hline $\begin{array}{l}\text { Positive attitude } \\
\text { towards life }\end{array}$ & 3,921 & 0,923 & $-0,808$ & 0,186 & 4,053 & 0,895 & $-1,143$ & 1,222 \\
$\begin{array}{l}\text { Positive } \\
\text { Affectivity }\end{array}$ & 3,664 & 1,00 & $-0,696$ & 0,090 & 3,706 & 0,984 & $-0,766$ & 0,288 \\
Femininity & 3,482 & 0,836 & $-0,555$ & 0,763 & 3,786 & 0,792 & $-0,593$ & 0,897 \\
Masculinity & 2,793 & 0,979 & $-0,001$ & $-0,519$ & 2,406 & 0,965 & 0,264 & $-0,499$ \\
Cohesion & 3,908 & 0,751 & $-0,787$ & 0,805 & 4,060 & 0,690 & $-0,719$ & 0,336 \\
Flexibility & 3,145 & 0,609 & 0,044 & 0,838 & 3,212 & 0,566 & 0,062 & 0,331 \\
Communication & 4,082 & 0,811 & $-0,909$ & 1,027 & 4,100 & 0,835 & $-0,915$ & 0,672 \\
\hline
\end{tabular}

When it comes to the indicators of normality of distributions we can notice that skewness and kurtosis of positive attitude towards life on the female sample, and kurtosis of communication on male sample are slightly above the threshold $(<1,00)$. Having in mind the size of the sample we could expect that this values of skewness and kurtosis would not influence the results (Palant, 2009).

Table 2. Gender differences in the level of Positive attitude towards life and Positive affect

\begin{tabular}{|c|c|c|c|c|c|}
\hline & Group & $\mathrm{N}$ & $\mathrm{M}$ & $\mathrm{T}$ test & $\mathrm{p}$ \\
\hline Positive attitude towards life & $\begin{array}{c}\text { Males } \\
\text { Females }\end{array}$ & $\begin{array}{l}585 \\
799\end{array}$ & $\begin{array}{l}3,921(0,923) \\
4,053(0,895)\end{array}$ & $-2,669$ & 0,008 \\
\hline Positive affect & $\begin{array}{c}\text { Males } \\
\text { Females }\end{array}$ & $\begin{array}{l}585 \\
799\end{array}$ & $\begin{array}{l}3,664 \quad(1,00) \\
3,706(0,984)\end{array}$ & $-0,785$ & 0,432 \\
\hline
\end{tabular}

According to the results presented in Table 2 we can see that there are statistically significant differences between genders on variable Positive attitude towards life, whereby women have higher scores. Using the formula to calculate eta square coefficient (eta square $=\mathrm{t}^{2} / \mathrm{t}^{2}+(\mathrm{N} 1+\mathrm{N} 2-2)$ ) (according to Palant, 2009), it is showed that the effect size of gender on Positive attitude towards life is very low (eta square $=0,005$ ). It also proved that men and women do not differ when it comes to the level of Positive affect.

The results presented in Table 3 show that on the male subsample positive attitude towards life is in moderate positive correlation with cohesion and communication, and in weak positive correlation with femininity, masculinity, flexibility and the level of education. Positive affectivity is in moderate positive correlation with cohesion and communication, and in weak positive correlation with femininity, masculinity and flexibility. 
Table 3. Correlation between variables on male subsample

\begin{tabular}{lcccccccc}
\hline & 1 & 2 & 3 & 4 & 5 & 6 & 7 & 8 \\
\hline $\begin{array}{l}\text { 1. Positive attitude } \\
\text { towards life }\end{array}$ & $/$ & & & & & & & \\
2. Positive Affectivity & $0,721^{* *}$ & & & & & & \\
3. Femininity & $0,217^{* *}$ & $0,202^{* *}$ & & & & & \\
4. Masculinity & $0,167^{* *}$ & $0,278^{* *}$ & $0,153^{* *}$ & & & & & \\
5. Cohesion & $0,394^{* *}$ & $0,353^{* *}$ & $0,317^{* *}$ & 0,050 & & & & \\
6. Flexibility & $0,180^{* * *}$ & $0,167^{* * *}$ & $0,174^{* *}$ & $0,096^{*}$ & $0,462^{* *}$ & & & \\
7. Communication & $0,366^{* *}$ & $0,348^{* * *}$ & $0,245^{* *}$ & 0,028 & $0,728^{* *}$ & $0,437^{* *}$ & & \\
8. Education & $0,101^{*}$ & 0,061 & $0,144^{* *}$ & $0,117^{* *}$ & 0,078 & 0,069 & $0,090^{* *}$ & \\
9. Number of children & $-0,003$ & $-0,048$ & 0,013 & $-0,145^{* *}$ & $0,108^{*}$ & 0,039 & 0,012 & $-0,077$ \\
\hline *** correlation is significant at the 0,01 level & & & & & \\
*correlation is significant at the 0,05 level & & & & &
\end{tabular}

Table 4. Correlation between variables on female subsample

\begin{tabular}{|c|c|c|c|c|c|c|c|c|}
\hline & 1 & 2 & 3 & 4 & 5 & 6 & 7 & 8 \\
\hline $\begin{array}{l}\text { 1. Positive attitude } \\
\text { towards life }\end{array}$ & I & & & & & & & \\
\hline 2. Positive Affectivity & $0,712^{* *}$ & & & & & & & \\
\hline 3. Femininity & $0,144^{* *}$ & 0,051 & & & & & & \\
\hline 4. Masculinity & $0,116^{* *}$ & $0,133^{* *}$ & $0,327^{* *}$ & & & & & \\
\hline 5. Cohesion & $0,261^{* *}$ & $0.228^{* *}$ & $0,132^{* *}$ & -0.023 & & & & \\
\hline 6. Flexibility & $0,095^{* *}$ & $0,091^{*}$ & $0,239^{* *}$ & $0.125^{*}$ & $0,441^{* *}$ & & & \\
\hline 7. Communication & $0,290^{* *}$ & $0,279^{* *}$ & 0,011 & -0.016 & $0,714^{* *}$ & $0,410^{* * *}$ & & \\
\hline 8. Education & $0,109^{* *}$ & $0,104^{* *}$ & 0,057 & $0,194^{* * *}$ & 0,027 & 0,048 & $-0,024$ & \\
\hline 9. Number of children & $-0.076^{*}$ & $-0,124^{* *}$ & $0,327^{* *}$ & $-0,072$ & $0,093^{*}$ & 0,024 & 0,046 & $-0,164^{* *}$ \\
\hline
\end{tabular}

When it comes to the female subsample, it showed that positive attitude towards life is in weak positive correlation with femininity, masculinity, cohesion, flexibility, communication and the level of education, and in weak negative correlation with the number of children (Table 4). On the other hand, positive affectivity is in weak, positive, and statistically significant correlation with masculinity, cohesion, flexibility, communication and the level of education, and in weak negative correlation with the number of children.

\section{Hierarchical Regression Analysis}

Hierarchical regression analyses were used to estimate the relative contributions of the independent variables (femininity, masculinity, cohesion, flexibility, communication, the level of education and the number of children) to the prediction of criterion variables (positive attitude towards life and positive affectivity) on both males and females. In that way, we can examine conjoint and separate contributions of predictors to criterion 
variables. The first step was to enter sociodemographic variables (the level of education and number of children); the second step to enter gender roles (femininity and masculinity), and the third to enter the variables of family functionality (cohesion, flexibility, and communication).

Table 5. Hierarchical regression analysis (Enter method) criterion variable Positive attitudes towards life-male sample

\begin{tabular}{|c|c|c|c|c|c|c|c|c|c|}
\hline & \multirow[b]{2}{*}{ Predictors } & \multicolumn{8}{|c|}{ Positive attitudes towards life } \\
\hline & & $\beta$ & $\mathrm{p}$ & Tolerance & VIF & $\mathrm{R}^{2}$ & $\mathrm{p}$ & $\Delta \mathrm{R}^{2}$ & $\mathrm{p}$ \\
\hline \multirow[b]{2}{*}{ I } & Education & 0,106 & 0,015 & 0,993 & 1,007 & \multirow{2}{*}{\multicolumn{2}{|c|}{$0,011 \quad 0,050$}} & & \\
\hline & Number of children & 0,001 & 0,984 & 0,993 & 1,007 & & & & \\
\hline \multirow{4}{*}{ II } & Education & 0,061 & 0,150 & 0,963 & 1,038 & \multirow{4}{*}{0,067} & \multirow{4}{*}{0,000} & \multirow{4}{*}{0,063} & \multirow{4}{*}{0,000} \\
\hline & Number of children & 0,012 & 0,782 & 0,973 & 1,028 & & & & \\
\hline & Femininity & $\mathbf{0 , 2 0 7}$ & 0,000 & 0,964 & 1,037 & & & & \\
\hline & Masculinity & $\mathbf{0 , 1 2 7}$ & 0,003 & 0,956 & 1,046 & & & & \\
\hline \multirow{7}{*}{ III } & Education & 0,045 & 0,256 & 0,961 & 1,040 & & \multirow{7}{*}{0,000} & \multirow{7}{*}{0,125} & \multirow{7}{*}{0,000} \\
\hline & Number of children & $-0,014$ & 0,731 & 0,945 & 1,059 & & & & \\
\hline & Femininity & 0,102 & 0,014 & 0,878 & 1,139 & & & & \\
\hline & Masculinity & $\mathbf{0 , 1 3 5}$ & 0,001 & 0,950 & 1,053 & 0,189 & & & \\
\hline & Cohesion & 0,246 & 0,000 & 0,405 & 2,466 & & & & \\
\hline & Flexibility & $-0,059$ & 0,191 & 0,747 & 1,339 & & & & \\
\hline & Communication & $\mathbf{0 , 1 7 9}$ & 0,002 & 0,440 & 2,274 & & & & \\
\hline
\end{tabular}

Significant predictors of positive attitude towards life on the sample of males are femininity, masculinity, cohesion and communication (Table 5).

Table 6. Hierarchical regression analysis (method Enter) criterion variable Positive affectivity - male sample

\begin{tabular}{|c|c|c|c|c|c|c|c|c|c|}
\hline & & \multicolumn{8}{|c|}{ Positive affectivity } \\
\hline & Predictors & $\beta$ & $\mathrm{p}$ & Tolerance & VIF & $\mathrm{R}^{2}$ & $\mathrm{p}$ & $\Delta \mathrm{R}^{2}$ & $\mathrm{p}$ \\
\hline \multirow[t]{2}{*}{$\mathrm{I}$} & Education & 0,061 & 0,161 & 0,992 & 1,008 & \multirow{2}{*}{\multicolumn{4}{|c|}{$0,006 \quad 0,181$}} \\
\hline & Number of children & $-0,047$ & 0,281 & 0,992 & 1,008 & & & & \\
\hline \multirow{4}{*}{ II } & Education & 0,005 & 0,911 & 0,960 & 1,042 & \multirow{4}{*}{0,112} & \multirow{4}{*}{\multicolumn{2}{|c|}{$0,0000,105$}} & \multirow{4}{*}{0,000} \\
\hline & Number of children & $-0,019$ & 0,649 & 0,972 & 1,029 & & & & \\
\hline & Femininity & $\mathbf{0 , 1 8 0}$ & 0,000 & 0,963 & 1,038 & & & & \\
\hline & Masculinity & 0,256 & 0,000 & 0,956 & 1,046 & & & & \\
\hline \multirow{7}{*}{ III } & Education & $-0,005$ & 0,903 & 0,959 & 1,043 & \multirow{7}{*}{0,226} & \multirow{7}{*}{0,000} & & \multirow{7}{*}{0,000} \\
\hline & Number of children & $-0,040$ & 0,309 & 0,944 & 1,060 & & & & \\
\hline & Femininity & 0,077 & 0,061 & 0,874 & 1,144 & & & & \\
\hline & Masculinity & 0,261 & 0,000 & 0,950 & 1,052 & & & 0,114 & \\
\hline & Cohesion & 0,229 & 0,000 & 0,408 & 2,451 & & & & \\
\hline & Flexibility & $-0,054$ & 0,219 & 0,751 & 1,331 & & & & \\
\hline & Communication & 0,176 & 0,002 & 0,443 & 2,260 & & & & \\
\hline
\end{tabular}


694

According to Table 6, we can see that significant predictors of positive affectivity in males are masculinity, cohesion and communication.

Table 7. Hierarchical regression analysis (Enter method) criterion variable Positive attitudes towards life - female sample

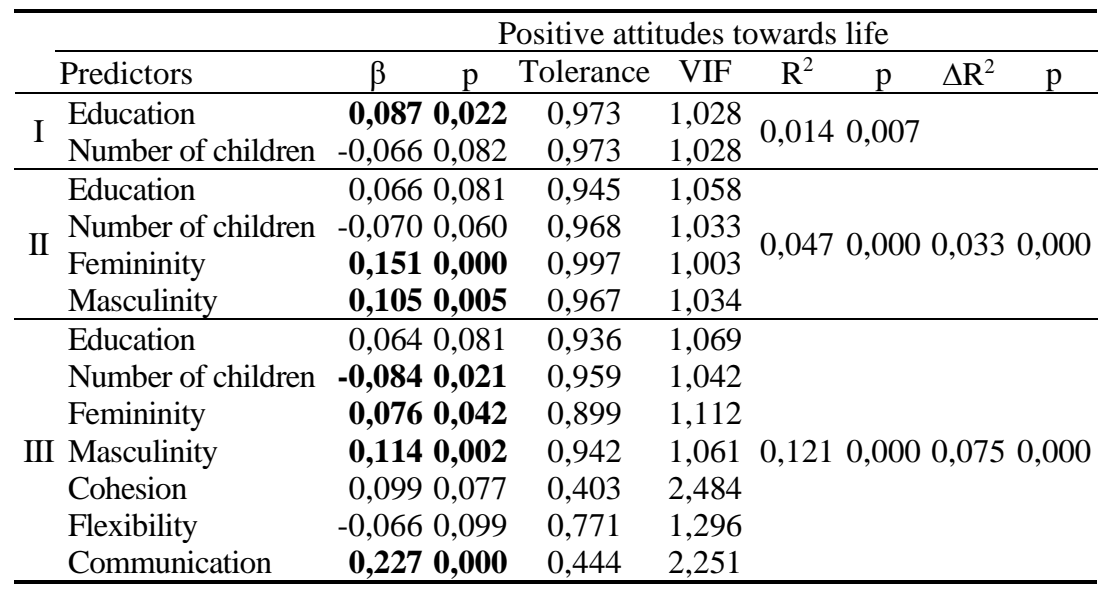

Significant predictors of positive attitude towards life on the sample of females are femininity, masculinity and communication, and in negative direction, the number of children (Table 7).

Table 8. Hierarchical regression analysis (Enter method) criterion variable Positive affectivity - female subsample

\begin{tabular}{|c|c|c|c|c|c|c|c|c|c|}
\hline & \multicolumn{9}{|c|}{ Positive affectivity } \\
\hline & Predictors & $\beta$ & $\mathrm{p}$ & Tolerance & VIF & $\mathrm{R}^{2}$ & $\mathrm{p}$ & $\Delta \mathrm{R}^{2}$ & $\mathrm{p}$ \\
\hline \multirow{2}{*}{ I } & Education & $\mathbf{0 , 0 7 5}$ & 0,047 & 0,973 & 1,028 & \multirow{2}{*}{\multicolumn{2}{|c|}{$0,022 \quad 0,000$}} & & \\
\hline & Number of children & $-0,115$ & 0,002 & 0,973 & 1,028 & & & & \\
\hline \multirow{4}{*}{ II } & Education & 0,051 & 0,176 & 0,944 & 1,059 & \multirow{4}{*}{0,042} & \multirow{4}{*}{0,000} & \multirow{4}{*}{0,019} & \multirow{4}{*}{0,000} \\
\hline & Number of children & $-0,118$ & 0,002 & 0,969 & 1,032 & & & & \\
\hline & Femininity & 0,057 & 0,119 & 0,997 & 1,003 & & & & \\
\hline & Masculinity & 0,127 & 0,001 & 0,966 & 1,036 & & & & \\
\hline \multirow{7}{*}{ III } & Education & 0,049 & 0,184 & 0,935 & 1,070 & \multirow{7}{*}{0,122} & \multirow{7}{*}{0,000} & \multirow{7}{*}{0,080} & \multirow{7}{*}{0,000} \\
\hline & Number of children & $-0,134$ & $\mathbf{0 , 0 0 0}$ & 0,959 & 1,043 & & & & \\
\hline & Femininity & $-0,020$ & 0,590 & 0,903 & 1,107 & & & & \\
\hline & Masculinity & 0,136 & 0,000 & 0,942 & 1,061 & & & & \\
\hline & Cohesion & 0,101 & 0,067 & 0,407 & 2,458 & & & & \\
\hline & Flexibility & $-0,064$ & 0,111 & 0,772 & 1,295 & & & & \\
\hline & Communication & 0,234 & 0,000 & 0,448 & 2,234 & & & & \\
\hline
\end{tabular}

In Table 8 , we can see that significant predictors of positive affectivity of females are masculinity and communication, and in the negative direction, the number of children. 


\section{DISCUSSION}

The main aim of this study was to provide a better understanding of subjective well-being of men and women in the Republic of Serbia by examining the specific contribution of gender roles, the dimensions of family functioning, the level of education, and the number of children.

First, the results showed that there are statistically significant differences between genders in positive attitude towards life, whereby women have higher scores then men, although the effect size of this difference is quite low. Similar results are observed in certain previous research as well (Blanchflower \& Oswald, 2004). On the other hand, there is no difference between men and women when it comes to the level of positive affect, and this result is also in line with previous research (Zuckerman, Li, \& Diener, 2017).

Moreover, significant predictors of positive attitude towards life in men are femininity, masculinity, cohesiveness and communication, and in women are femininity, masculinity and communication, and in the negative direction, it is the number of children. Significant predictors of positive affectivity in men are masculinity, cohesion and communication, and in women, they are masculinity and communication, and in the negative direction, the number of children.

To summarize, we noticed that femininity, masculinity, and communication, are significant predictors of positive attitude towards life in both men and women. It is important to remember that positive attitude towards life represents the cognitive component of subjective well-being that reflects not only satisfaction with life in general, but also satisfaction in relation to specifically important domains of one's life, such as marriage, family, work, friends (Hadži Pešić \& Anđelković, 2013). According to that, the level of satisfaction with life is in relation to fulfillment not just physical and financial needs, but also the psychological ones. As expected, both masculinity and femininity represent important factors for the better understanding of the cognitive aspect of subjective well-being. To be specific, dominance and competition, on the one hand, and openness towards others, in the form of cordiality and sensitivity to their needs, on the other, contribute significantly to positive attitude towards life. On a more general level, the obtained results at least partially represent confirmation and verification of Jung's ideas that on the road to achieving greater psychological integrity, an individual must first become aware of his/her "man"/"woman" in him-/herself i.e. animus and anime. This idea was later formulated by Bem through the concept of androgyny, that refers to a high presence of positive characteristics of masculinity and femininity in a person.

Further, masculinity and communication showed as significant predictors of the affective dimension of subjective well-being in both men and women. Bearing in mind that masculinity represents the active, assertive attitude towards both self and others, ambition, physical strength, competitive 
spirit, rationality, successfulness, dominance, self-confidence, the capability of taking risks, courage, etc., the presence of high masculinity also indicates a high level of agency - the feeling that the person is in charge of his/her own life. The sense that one holds their own fate in their hands is a key factor in coping with stress, but also in dealing with difficulties and problems motivating us to persist on the road to success. Similar results are obtained and in some previous studies. For example, Eddington and Shuman (2005) stated that men and women who are agentic have higher subjective well-being, while men and women who are low in agency have lower level of subjective well-being. These results are confirmed in our study as well. Masculinity showed as an important factor that contributes to positive affect and positive attitude towards life, or better to say to overall subjective well-being in both samples.

Clear and open communication contributes uniquely to greater functionality not only on the level of family system, but also and in the functionality of each family member, so its role in subjective well-being is not surprising. Namely, in study done by Olson (cited in Čudina-Obradović \& Obradović, 2006) on the sample of 21.501 married couples, it showed that in happy marriages $90 \%$ of partners report that they do not have problems in communication, whereby in unhappy marriages that was stated only by $15 \%$ of partners. In line with that, Barker (1992) emphasizes that satisfaction with communication is an important factor in satisfaction with marriage, family, as well with life in general. Bearing in mind that the capacity for open, clear, assertive communication, for listening to the partner, or a family member, and after all other people, assimilates the characteristics of both gender roles, opens the question of whether masculinity and femininity contribute to subjective well-being at least partly through assertive communication?

Cohesion, as another aspect of family relations, showed as a significant predictor of both positive attitude towards life and positive affectivity, but only in men. Namely, social interactions provide the opportunity in which self-realization and fulfilment take place through shared identities, such as families and communities (Lin, 1999; cited in Lamu \& Olsen, 2016), which reflects on well-being, too. It is easy to understand that the feeling of closeness and connection with family members has a significant role when it comes to cognitive and affective dimension of subjective well-being, especially in men as we can see. On the other hand, an important factor of women's subjective well-being is the number of children. Namely, with the increase in the number of children, positive attitude towards life and positive affectivity decreases. The obtained results could be understood in line with the already existing findings that although employed, women still do most of the housework and care pertaining to children. Such position of women demands continuous balancing between work and family, which is often followed by greater stress (Jugović, 2004; cited in Mihić \& Filipović, 2012). It seems that a great number of women are still in some 
kind of transitory period. At work they are becoming even more equal, while at the same time, in the context of family, they are still facing traditional expectations. Undoubtedly, the increase in the number of children also increases the amount of demands and obligations at home. Thus, many women do not have enough time for some other activities such as hobbies, recreation, joint time with their partner, which all have significant impact on life satisfaction and positive emotions.

The sample size, and actuality and importance of the subject matter of this research, are some of the advantages of this research. Understanding subjective well-being through the concepts of masculinity and femininity, but also through the dimensions of family functioning, undoubtedly contribute to the existing corpus of research. Still, present research is followed by a few limitations. Firstly, we have to take a closer look at the instruments. Some of the scales showed a lower level of reliability. Namely, as we indicated and in some previous research (Olson \& Gorall, 2003; Olson \& Gorall 2007; Matejević \& Todorović, 2012), the dimension of family function - flexibility showed an unsatisfactory level of reliability, indicating the need for further improvement.

Finally, we could say that for positive attitude towards life it is important not only to focus on one's own well-being, but also on the wellbeing of others, as well adequate family communication. On the other hand, positive affectivity is related to masculinity and communication in both men and women. Furthermore, cohesiveness is an important factor of subjective well-being in the sample of men, while the number of children had a negative effect on both dimensions of subjective well-being, but only in women.

\section{CONCLUSION}

Understanding factors which are important for subjective well-being means understating the factors that cause better health and longevity (Diener \& Chan, 2011). According to the obtained results, the need for a more specific approach in the understanding of subjective well-being for both men and women is recognized. The need for dominance and competition, on the one hand, and adequate communication within the family on the other, are important resources for the subjective well-being of both genders. However, it seems that strengthening family cohesion and that working on joint agreement in the sharing of household responsibilities and responsibilities about children, represent significant places for therapeutic interventions in men and women, respectively, with the aim of improving their subjective well-being.

ACKNOWLEDGMENT: This study was financially supported by Faculty of Philosophy, University of Niš, Serbia (number of the Project 183/1-16-9-01). 


\section{REFERENCES}

Anđelković, V., Vidanović, S., Hedrih, V. (2012). Povezanost percepcije važnosti potreba djece, kvalitete života i obiteljskih te poslovnih uloga. [Relationship between perceptions of children's needs importance, quality of life and family and work roles]. Ljetopis socijalnog rada, 19 (2), 297-316.

Barker, Ph. (1992). Basic Family Therapy (Third Edition). London: Blackwell Scientific Publications.

Batz-Barbarich, C., Tay, L., Kuykendall, L., \& Cheung, H. K. (2018). A meta-analysis of gender differences in subjective well-being: estimating effect sizes and associations with gender inequality. Psychological science, 29(9), 1491-1503.

Batz, C., \& Tay, L. (2018). Gender differences in subjective well-being. In E. Diener, S. Oishi, \& L. Tay (Eds.), Handbook of well-being. Salt Lake City, UT: DEF Publishers.

Bem, S. L. (1975). Sex-role adaptability: one consequence of psychological androgyny. Journal of Personality and Social Psychology, 31, 634-643.

Blanchflower, D. G., \& Oswald, A. J. (2004). Well-being over time in Britain and the USA. Journal of Public Economics, 88(7), 1359-1386.

Botha, F., \& Booysen, F. (2014). Family Functioning and Life Satisfaction and Happiness in South Households, Social Indicators Research, 119(1), 163182. DOI: 10.1007/s11205-013-0485-6

Čudina - Obradović, M., Obradović, J. (2006). Psihologija braka i obitelji, [Psychology of marriage and family]. Zagreb: Golden marketing-Tehnička knjiga.

Diener, E., \& Chan, M. Y. (2011). Happy people live longer: Subjective well-being contributes to health and longevity. Applied Psychology: Health and Well-Being, $3(1), 1-43$.

Dragišić- Labaš, S. (2002). Porodične uloge i mogućnost usmeravanja porodičnog sistema na tradicionalne obrasce življenja [Family roles and the ability to direct the family system to traditional patterns of living] Engrami, 24, 23-30.

Eddington, N., \& Shuman, R. (2005). Subjective well-being (happiness). Continuing psychology education, 6 .

Evans, M. D. R., \& Kelley, J. (2004). Effect of family structure on life satisfaction: Australian evidence. Social indicators research, 69(3), 303349. DOI:10.1007/s11205-004-5578-9

Fujita, F., Diener, E., \& Sandvik, E. (1991). Gender differences in negative affect and well-being: The case for emotional intensity. Journal of Personality and Social Psychology, 61(3), 427-434.

Hadži-Pešić, M., Anđelković, V. (2013). Subjektivno blagostanje [Subjective wellbeing]. In (Eds.) V. Hedrih, J. Todorović i M. Ristić, Odnosi na poslu i u porodici u Srbiji početkom 21. veka, str. 181-189. Niš: Filozofski fakultet.

Hedrih, V., Simić, I. \& Ristić, M. (2013). Odnosi na poslu i u porodici u Srbiji metodologija istraživanja [Relations on work and in famliy in Serbia - metodology of research]. In (Eds.) V. Hedrih, J. Todorović i M. Ristić, Odnosi na poslu i u porodici u Srbiji početkom 21. veka, pp. 191-214. Niš: Filozofski fakultet.

Kandido-Jakšić, M. (1995). Polne uloge i mentalno zdravlje [Gender roles and mental health]. Psihologija, 28, 3-4.

Kouneski, E. F. (2000). The family circumplex model, FACES II, and FACES III: Overview of research and applications. University of Minnesota: Twin Cities.

Lamu, A. N., \& Olsen, J. A. (2016). The relative importance of health, income and social relations for subjective well-being: an integrative analysis. Social Science \& Medicine, 152, 176-185.

Joshi, U. (2010). Subjective well-being by gender. Journal of Economics and Behavioral Studies, 1(1), 20-26. 
Jovanović, V. (2010). Validacija kratke skale subjektivnog blagostanja [Validation of Short Subjective well-being scale]. Primenjena psihologija, 3(2), 175-190.

Jovanović, V., Novović, Z. (2008). Kratka skala subjektivnog blagostanja - Novi instrument za procesnu pozitivnog mentalnog zdravlja [The Short Subjective well-being scale - new instrument for measurment of positive mental health]. Primenjena psihologija, 1 (1-2), 77-94.

Matejević, M., Todorović, J. (2012). Funkcionalnost porodičnih odnosa i kompetentno roditeljstvo [Functionality of family relationships and competent parenting]. Niš: Filozofski fakultet.

Meisenberg, G., \& Woodley, M. A. (2015). Gender differences in subjective wellbeing and their relationships with gender equality. Journal of Happiness Studies, 16(6), 1539-1555.

Mihić, V., \& Filipović, B. (2012). Povezanost podele posla i stava prema rodnim ulogama sa zadovoljstvom brakom zaposlenih supružnika. Primenjena psihologija, 5(3), 295-311.

Nikolaev, B. (2018). Does higher education increase hedonic and eudaimonic happiness?. Journal of happiness Studies, 19(2), 483-504.

Olson, D.H. (2000). Circumplex Model of Family Systems. Journal of Family Therapy. 22, 2, 144-167.

Olson, D.H. \& Gorall, D. M. (2003). Circumplex model of marital and family systems. In F. Walsh (Ed.) Normal Family Processes (3rd Ed). New York: Guiford (pp. 514-547).

Olson, D.H. \& Gorall, D. M. (2007). FACES IV and Circumplex model, Validation Study, St. Paul, MN: University of Minnesota.

Olson, D. (2011). FACES IV and the circumplex model: Validation study. Journal of marital and family therapy, 37(1), 64-80.

Okun, M. A., \& George, L. K. (1984). Physician-and self-ratings of health, neuroticism and subjective wellbeing among men and women. Personality and Individual Differences, 5(5), 533-539.

Palant, Dž. (2009). SPSS: Priručnik za preživljavanje [SPSS: Survival Manual]. Novi Sad: Mikor knjiga.

Read, S., \& Grundy, E. (2011). Mental health among older married couples: the role of gender and family life. Social psychiatry and psychiatric epidemiology, 46(4), 331-341.

Sari, E. P., \& Dahlia, W. (2018). Family Functioning and Subjective Well-Being among Adolescents. Malaysian Online Journal of Counseling, 5, 1, 43-51

Shields, M., \& Wooden, M. (2003). Marriage, children and subjective well-being. In 8th Australian Institute of Family Studies Conference. http://www. melbourneinstitute. com/hilda/Biblio/hbibliocq. html.

Soltanpanah, J., Parks-Stamm, E. J., Martiny, S. E., \& Rudmin, F. W. (2018). A crosscultural examination of the relationship between egalitarian gender role attitudes and life satisfaction. Sex Roles, 79(1-2), 50-58.

Stevenson, B., \& Wolfers, J. (2009). The paradox of declining female happiness (No. w14969). National Bureau of Economic Research.

Van De Vijver, F. J. (2007). Cultural and gender differences in gender-role beliefs, sharing household task and child-care responsibilities, and well-being among immigrants and majority members in the Netherlands. Sex Roles, 57(11-12), 813-824.

Zuckerman, M., Li, C., \& Diener, E. F. (2017). Societal conditions and the gender difference in well-being: Testing a three-stage model. Personality and Social Psychology Bulletin, 43(3), 329-336. 


\title{
ПОЛНЕ УЛОГЕ И ДИМЕНЗИЈЕ ПОРОДИЧНОГ ФУНКЦИОНИСАҢА КАО ПРЕДИКТОРИ СУБЈЕКТИВНОГ БЛАГОСТАҢА МУШКАРАЦА И ЖЕНА
}

\author{
Миљана Спасић Шнеле, Јелисавета Тодоровић, Мирослав Комленић \\ Универзитет у Нишу, Филозофски факултет, Ниш, Србија
}

\section{Резиме}

Субјективно благостање дефинише се као евалуација сопственог живота, која обухвата когнитивну (позитиван став према животу) и афективну (позитиван афективитет) компоненту. Друштвени фактори кроз одређена, најчешће различита, очекивања од мушкараца и жена, која се одражавају кроз социјално конструисане родне улоге, могу имати посебно место у доживљају субјективног благостања. Маскулина родна улога подразумева агресивност, амбициозност, такмичарски дух, доминантност, самопоуздање, способност преузимања ризика, храброст и борбеност особе, док феминина родна улога одражава емотивну страну личности, саосећајност, усмереност на потребе других. Доживљај благостања повезан је и са породичним функционисањем, где функционална породица пружа осећај сигурности и припадности и задовољава различите потребе својих чланова. Један од модела праћења образаца породичног функционисања јесте Циркумплекс модел брачног и породичног функционисања, који се заснива на димензијама кохезивности, флексибилност и комуникација. Имајући претходно речено у виду, циљ овог истраживања био је испитати ниво субјективног благостања 1417 испитаника (586 мушкараца, 802 жена), који су у браку или партнерској вези, путем испитивања концепата маскулиности и фемининости, као и димензија породичног функционисања. Као значајни предиктори позитивног става према животу мушкараца и жена показали су се маскулиност и фемининост указујући на то да, с једне стране, доминантност и склоност такмичењу, а са друге отвореност ка другима, у виду срдачности и сензитивности за њихове потребе, значајно доприносе позитивном ставу према животу. Када је реч о другој димензији субјективног благостања, показало се да маскулиност представља значајан предиктор позитивног афективитета и мушкараца и жена. Маскулиност представља активан, асертиван став према себи и другима, амбицију, склоност доминацији, храброст, указује и на висок ниво агентности, односно доживљаја особе да управља својим животом, што има посебно важну улогу у суочавању са стресом, али и мотивасању особе да истраје на путу ка успеху. Комуникација, као димензија породичних односа, такође представља значајан предиктор у односу на обе димензије субјективног благостања оба пола. Имајући на уму да јасна и отворена комуникација доприноси већој функционалности не само на нивоу породичног система већ и на индивидуалном нивоу сваког од чланова породице, не изненађује податак да има важну улогу и у доживљају субјективног благостања. Даље, кохезивност, као димензија породичне функционалности, има значајну улогу у субјективом благостању, али само на узорку мушкараца. Када је реч о особама женског пола, као значајан предиктор обе димензије субјективног благостања издвојио се и број деце. Показало се да се са повећањем броја деце смањује позитиван став према животу и позитивни афективитет, што се може разумети у контексту већ постојећих сазнања да у реалности, иако запослене ван куће, жене и даље обављају највећи део кућних послова и преузимају на себе највећи део бриге и неге деце. Сумирајући добијене резултате, можемо рећи да усмереност на сопствену добробит као и добробит других, заједно са адекватном комуникацијом у породици - представљају важне индикаторе пози- 
тивног става према животу мушкараца и жена. Маскулиност и комуникација имају значајну улогу када је реч о афективној димензији субјективног благостања код мушкараца и жена. На узорку мушкараца важну улогу има и ниво кохезивности, а код жена број деце. 